\title{
Predictors for Intensive Care Unit Admission in Acute Theophylline Intoxicated Patients
}

\author{
Heba .K. khalifa and Heba .I. Lashin ${ }^{1}$
}

${ }^{1}$ Department of Forensic Medicine and Clinical Toxicology. Faculty of Medicine, Tanta University, Tanta, Egypt.

\begin{abstract}
Theophylline remains the most widely pharmaceuticals for the treatment of acute and chronic asthma in several developing countries, as it is effective, cheap, and widely available. Few studies were investigated to predict the need of ICU admission based on clinical parameters recorded at admission. Hence, this study aimed to identify the predictors for ICU admission in acute theophylline intoxicated patients. It was carried out on one hundred and ten acutely theophylline poisoned patients who were admitted to Poison Control Unit, Emergency Hospital, Tanta University over a period of two years. For each patient, full sociodemographic, toxicological, clinical examination and routine laboratory investigations \& serum theophylline level were done. Then, all findings of acute theophylline poisoned patients were analyzed against ICU admission. Statistical significant associations were found between ICU admission and gender, dose, CNS manifestations (agitations, hallucinations and tremors), hypotension, serum potassium and serum theophylline level. Logistic regression of clinically relevant variable showed that, patients who presented with hallucination, agitation, or hypotension had an increased likelihood of requiring admission to ICU and could correctly predicted $98.2 \%$ of cases. ROC curve analysis of serum theophylline accuracy revealed that, serum level $\geq 37.5 \mathrm{mg} / \mathrm{L}$ is a fair predictor for ICU admission. It could be concluded that, in acute theophylline intoxicated patients, hallucination, agitation and hypotension could be considered as good predictors for ICU admission. While, patients who had serum theophylline level $\geq 37.5 \mathrm{mg} / \mathrm{L}$ should be admitted in ICU as high risk patients.
\end{abstract}

\begin{tabular}{l|l} 
Keywords & Theophylline; Acute Toxicity; Intensive Care Unit; Predictors.
\end{tabular}

\section{Introduction}

$\mathrm{T}$ Theophylline is a dimethylxanthine that remains the most widely pharmaceuticals for the treatment of acute and chronic asthma in several developing countries, as it is effective, cheap, and widely available. Moreover, it is used as a smooth muscle relaxant, myocardial stimulant and diuretic agent (Amin et al., 2003; Wu et al., 2013).

The toxicity by theophylline may be acute, acute on therapeutic or chronic. Acute theophylline intoxication may results from single ingestion of more than $10 \mathrm{mg} / \mathrm{kg}$. Acute on therapeutic intoxication results when theophylline-treated patients ingest a toxic dose (Henry and Minton, 2011). Furthermore, its therapeutic use may be associated with toxicity due to its narrow therapeutic index, variable individual pharmacokinetics and development of sustained release formulations (Boushey, 2011).

The mechanism of toxicity of theophylline and other methylxanthines is through adenosine receptors antagonism, increasing the release of endogenous catecholamines, inhibition of phoshodisterase enzyme and increasing of C-AMP by prevention of its degradation (Paul et al., 2010; Ghannoum et al., 2015).

Theophylline poisoning is associated with many gastrointestinal, neurologic, musculoskeletal and cardiovascular manifestations and often leads to important body systems complications. Nausea, vomiting, abdominal pain, tachycardia, hematemesis, coarse muscle tremors and hypotension may occur. Moreover, many metabolic disturbances are reported e.g. hypokalemia, hyperglycemia, hypercalcemia and metabolic acidosis (Kapoor et al., 2015).

Furthermore, theophylline intoxication can also lead to life-threatening events like refractory seizures, cardiac arrhythmias that characteristically appear without warning and are relatively resistant to standard therapeutic measures and eventually lead to cardiac arrest (Minton and Henry, 1996; Koeijers et al., 2008).

The incidence of acute poisoned patients who required intensive care unit (ICU) admission was ranged between $2 \%$ to $13.8 \%$ of all admitted cases to ICUs (Liisanantti et al., 2011). To the best of our knowledge, few studies were investigated to predict the need of 
ICU admission based on clinical parameters recorded at admission. This might enable clinicians to identify patients at high risk after presentation allowing more intensive monitoring and treatment that will be useful especially in developing countries (Davies et al., 2008).

Unfortunately, acute theophylline toxicity is still a big problem with major consequences especially in developing countries. This was attributed to lack of specific antidote and the presence of many factors that may affect the outcome of acute theophylline intoxicated patients. So, physicians are in need for recognizing morbidity and mortality risk factors in those patients soon after presentation. This might allow more intensive treatment and monitoring, and thereby decrease complications (El-Hawary et al., 2015). Hence, the target of this study is to identify the predictors that may be useful in determining the need of ICU admission in cases of acute theophylline toxicity.

\section{Patients and methods}

This prospective observation cross sectional study was carried out on 110 patients who received detailed information concerning the aim of the research work. A written informed consent was obtained from each participant or his guardian prior to study beginning. The study was accepted by the Research Ethical Committee, Faculty of Medicine, Tanta University. Privacy and confidentiality of patients' records and data was ascertained through coding system.

Inclusion criteria:

All adult patients with history and/or manifestations of acute theophylline toxicity who were admitted to Poison Control Unit, Emergency Hospital, Tanta University in the period from January 2016 till December 2017 were included.

Exclusion criteria:

Patients who received any unreported medical treatment before admission.

Patients who co-ingested substances.

Patients with any pre-existing chronic diseases including; cardiac diseases, hypertension, diabetes,influenza, hepatic and renal diseases and cancer.

Smokers.

Diagnosis of acute theophylline toxicity was based on history of theophylline intake and/or manifestations of acute theophylline toxicity together with estimation of serum theophylline level.

For each patient, full history was taken including the sociodemographic data, past history of any chronic systemic illness with especial concern to bronchial asthma and toxicological data including route \& mode of poisoning, previous intake of theophylline, formulation of the drug, dose, and any intervention occurred \& time elapsed before hospital admission. In addition, vital signs, level of consciousness according to Glasgow Coma Scale (GCS), gastrointestinal, neurological and cardiovascular manifestations were recorded.
The normal ranges of vital signs varies according to age, where the normal ranges of blood pressure (mmHg), pulse (beats/min.) and temperature $\left({ }^{\circ} \mathrm{C}\right)$ in adults are $90-130 / 60-90,60-100$ and $37+0.6$ respectively (Flomenbaum et al., 2006). As regards vital signs in children, the normal range of temperature is (36.6-37.9 ${ }^{\circ} \mathrm{C}$ rectally) (Nield and Kamat, 2011). While, the normal ranges of other vital signs of patients below 18 years are determined according to standardized blood pressure and pulse tables (Hartman and Cheifetz, 2011).

Under complete aseptic conditions, venous blood samples were taken immediately after admission and before giving any medication in disposable blood collection syringes. They were used for serum potassium and random blood sugar measurements. Serum theophylline levels were measured according to Sheehan and Haythorn (1976).

Finally, the need for ICU admission and the duration of hospital stay for each patient was recorded with all other data in a standard sheet that was designed to record complete clinical assessment of each patient.

\section{Statistical analysis:}

For quantitative data, the Shapiro-Wilk test for normality was performed. For data that were not normally distributed, median and mean ranks were calculated and Mann-Whitney $U$ test was used for comparison between groups. For qualitative data, they were expressed as numbers and percentages and Pearson's Chi square test was used to examine association between two variables. When more than $20 \%$ of cells have expected count less than 5, Fisher's Exact test was used. Additionally, binary logistic regression was performed to ascertain the effects of clinically relevant variables on the likelihood that participants will need ICU admission. The predictive role of serum theophylline level was analyzed by Receiver Operating Characteristics (ROC) curve. Significance was adopted at $\mathrm{p}<0.05$ for interpretation of results of tests. All analyses were done using SPSS version 20 (Knapp, 2017).

\section{Results}

Table (1) revealed that, patients' ages ranged between 1 and 59 years (median: 20); females represented 92 patients (83.6\%). Suicidal attempts were recorded in 105 of patients (95.5\%). Oral route was registered in 109 cases (99.1\%). Ninety four and half percent of poisoned patients were presented with acute overdose. Number of tablets taken by patients ranged between one tablet to twenty tablets with a median 5 tablets, each tablet contained $400 \mathrm{mg}$ of theophylline. Pre hospital delay ranged between 1-26 hours with a median 6 hours.

Table (2) showed distribution of different clinical manifestations and laboratory findings of the studied patients. Gastrointestinal manifestations were in the form of nausea,vomiting, hematemesis and diarrhea. Nausea was found in 92 patients (83.6\%), 10 patients of them admitted to ICU . Vomiting occurred in 99 patients (90\%) ; 9 patients of them admitted to ICU. Eight patients (7.3\%) presented with hematemsis and 7 of them 
admitted to ICU .Diarrhea occurred in 4 patients and only one of them admitted to ICU. Hypotension was reported only in $11.8 \%$ of patients, while most of them (90\%) suffered from tachycardia. Tremors were reported in 35 patients (31.8\%), agitation occurred in 8 patients (7.3\%), only 2 patients suffered from hallucination while only one case developed seizures. The median serum theophylline level among the studied patients was 35 $\mathrm{mg} / \mathrm{L}$. Serum glucose level elevated (>140) in $26.4 \%$ of patients. $74.5 \%$ of patients presented with hypokalemia, while $24.5 \%$ of patients with normal potassium level and only one patient had hyperkalemia.

There was no statistically significant association between age of the patients and need for ICU admission, but gender showed statistically significant association with need for ICU admission. No statistically significant association was found between mode of toxicity, preexisting disease, route of ingestion, type of toxicity, form of theophylline preparation and delay time with need for ICU admission. However, dose of theophylline showed statistically significant association with the need for ICU admission as illustrated in table (3).

No statistically significant association was found between any of gastrointestinal manifestations and need for ICU admission. However, statistically significant association between tremors, agitation, hallucination and the need for ICU admission was detected as illustrated in table (4).

Table (5) shows statistically significant association between blood pressure of the studied patients and need for ICU admission. Conversely, no statistically significant association was reported between each of pulse rate, temperature and need for ICU admission. Statistically significant association was shown between serum theophylline level, serum potassium level and need for ICU admission.

A logistic regression was performed to ascertain effect of clinically relevant variable on need to ICU admission (table 6). It was found that, patients who presented with hallucination, agitation, or hypotension had significantly increased likelihood of requiring admission to ICU (131.85, 8.85, and 4.91 times respectively).

For assessment of serum theophylline level accuracy in predicting the need for ICU admission in acute theophylline poisoned patients, ROC curve was constructed. It revealed that, area under curve was 0.75 $\left(\mathrm{p}=0.010^{*}\right)$ that means fair accuracy. The optimal cut-off value was $\geq 37.5 \mathrm{mg} / \mathrm{L}$ as shown in table (7) and figure (1).

Table 1: Sociodemographic and toxicological distribution of acute theophylline intoxicated patients $(\mathrm{n}=110)$

\begin{tabular}{|c|c|c|c|}
\hline \multicolumn{2}{|c|}{ Characteristic parameters } & \multirow{2}{*}{$\begin{array}{c}\begin{array}{c}\mathbf{n} \\
(\text { Total=110) }\end{array} \\
33\end{array}$} & \multirow{2}{*}{$\begin{array}{l}\% \\
30 \\
\end{array}$} \\
\hline Age groups (years) & $<18$ & & \\
\hline & $18-28$ & 64 & 58.18 \\
\hline & $29-40$ & 8 & 7.27 \\
\hline & $>40$ & 5 & 4.56 \\
\hline \multirow[t]{2}{*}{ Sex } & Male & 18 & 16.4 \\
\hline & Female & 92 & 83.6 \\
\hline \multirow[t]{2}{*}{ Pre-existing disease } & Yes & 9 & 8.2 \\
\hline & No & 101 & 91.8 \\
\hline \multirow[t]{2}{*}{ Route of toxicity } & Oral & 109 & 99.1 \\
\hline & Rectal & 1 & 0.9 \\
\hline \multirow[t]{2}{*}{ Mode of toxicity } & Alleged intentional & 105 & 95.5 \\
\hline & Alleged accidental & 5 & 4.5 \\
\hline \multirow[t]{2}{*}{ Type of toxicity } & Acute & 104 & 94.5 \\
\hline & Acute on top of chronic & 6 & 5.5 \\
\hline \multirow[t]{3}{*}{ Form } & Normal release & 75 & 68.2 \\
\hline & Sustained release & 35 & 31.8 \\
\hline & Minimum & Maximum & Median \\
\hline $\begin{array}{c}\text { Dose } \\
\text { (Tablet }=400 \mathrm{mg})\end{array}$ & 1 & 20 & 5 \\
\hline Delay (h) & 1 & 26 & 6 \\
\hline
\end{tabular}

n: number; h: hour 
Table 2: Clinical and laboratory findings of acute theophylline intoxicated patients $(\mathbf{n}=110)$

\begin{tabular}{|c|c|c|c|c|}
\hline \multicolumn{3}{|c|}{ Clinical and laboratory findings } & $\begin{array}{c}n \\
(\text { Total=110) }\end{array}$ & $\%$ \\
\hline \multirow[t]{6}{*}{ Vital signs } & \multirow{2}{*}{$\begin{array}{c}\text { Blood pressure } \\
\text { (mmHg) }\end{array}$} & Normal blood pressure & 97 & 88.2 \\
\hline & & Hypotension & 13 & 11.8 \\
\hline & \multirow[t]{2}{*}{ Pulse (beat/min.) } & Normal pulse & 11 & 10 \\
\hline & & Tachycardia & 99 & 90 \\
\hline & \multirow[t]{2}{*}{ Temperature $\left({ }^{\circ} \mathrm{C}\right)$} & Normal temperature & 107 & 97.3 \\
\hline & & Increased temperature & 3 & 2.7 \\
\hline \multirow{4}{*}{\multicolumn{2}{|c|}{ Gastrointestinal manifestations }} & Nausea & 92 & 83.6 \\
\hline & & Vomiting & 99 & 90 \\
\hline & & Diarrhea & 4 & 3.6 \\
\hline & & Hematemesis & 8 & 7.3 \\
\hline \multirow{4}{*}{\multicolumn{2}{|c|}{ Neurological manifestations }} & Tremors & 35 & 31.8 \\
\hline & & Agitations & 8 & 7.3 \\
\hline & & Hallucinations & 2 & 1.8 \\
\hline & & Seizures & 1 & 0.9 \\
\hline \multirow{2}{*}{\multicolumn{2}{|c|}{ Serum glucose level (mg/dl) }} & Normal (70-140) & 81 & 73.6 \\
\hline & & Hyperglycemia (> 140) & 29 & 26.4 \\
\hline \multirow{3}{*}{\multicolumn{2}{|c|}{ Serum Potassium level (mEq/L) }} & Normal $(3.5-5.5)$ & 27 & 24.5 \\
\hline & & Hypokalemia $(<3.5)$ & 82 & 74.5 \\
\hline & & Hyperkalemia (>5.5 ) & 1 & 0.9 \\
\hline \multirow{2}{*}{\multicolumn{3}{|c|}{ Serum theophylline level (mg/L) }} & Maximum & Median \\
\hline & & & 126 & 35.5 \\
\hline
\end{tabular}

n: number

Table 3: Association between ICU admission and acute theophylline intoxicated patients' sociodemographic and toxicological characteristics $(n=110)$

\begin{tabular}{|c|c|c|c|c|c|c|}
\hline \multirow{2}{*}{\multicolumn{3}{|c|}{ Characteristic parameters }} & \multirow{2}{*}{\multicolumn{2}{|c|}{ ICU admission }} & \multirow{2}{*}{\multicolumn{2}{|c|}{ Statistical tests }} \\
\hline & & & & & & \\
\hline \multirow{3}{*}{ Age (y) } & \multicolumn{2}{|c|}{ Minimum } & 5 & 1 & $7=$ & 0369 \\
\hline & \multicolumn{2}{|c|}{ Maximum } & 53 & 59 & 0.898 & \\
\hline & \multicolumn{2}{|c|}{ Median } & 18 & 20 & & \\
\hline \multirow[t]{2}{*}{ Gender } & Female & $\mathrm{n}(\%)$ & $5(50 \%)$ & $87(87 \%)$ & \multirow[t]{2}{*}{$X^{2}=6.59$} & \multirow{2}{*}{$\begin{array}{r}0.010 \\
* \quad\end{array}$} \\
\hline & Male & $\mathrm{n}(\%)$ & $5(50 \%)$ & $13(13 \%)$ & & \\
\hline \multirow{2}{*}{$\begin{array}{c}\text { Pre-existing } \\
\text { disease }\end{array}$} & Yes & $\mathrm{n}(\%)$ & $2(20 \%)$ & $7(7 \%)$ & \multirow{2}{*}{$\begin{aligned} & X^{2} \\
= & 0.681\end{aligned}$} & \multirow[t]{2}{*}{0.409} \\
\hline & No & n (\%) & $8(80 \%)$ & $93(93 \%)$ & & \\
\hline \multirow[t]{2}{*}{ Mode } & Accidental & $\mathrm{n}(\%)$ & $2(20 \%)$ & $3(3 \%)$ & \multirow[t]{2}{*}{$\mathrm{X}^{2}=2.77$} & \multirow[t]{2}{*}{0.096} \\
\hline & Suicidal & $\mathrm{n}(\%)$ & $8(80 \%)$ & 97 (97\%) & & \\
\hline \multirow[t]{2}{*}{ Route } & Oral & n (\%) & $10(100 \%)$ & 99 (99\%) & \multirow{2}{*}{$\begin{aligned} & X^{2} \\
= & 0.000\end{aligned}$} & \multirow[t]{2}{*}{1.00} \\
\hline & Rectal & $\mathrm{n}(\%)$ & $0(0 \%)$ & $1(1 \%)$ & & \\
\hline \multirow[t]{2}{*}{ Type of toxicity } & Acute & $\mathrm{n}(\%)$ & $9(90 \%)$ & $95(95 \%)$ & \multirow{2}{*}{$\begin{aligned} & X^{2} \\
= & 0.000\end{aligned}$} & \multirow[t]{2}{*}{1.00} \\
\hline & $\begin{array}{c}\text { Acute on top of } \\
\text { chronic }\end{array}$ & $\mathrm{n}(\%)$ & $1(10 \%)$ & $5(5 \%)$ & & \\
\hline \multirow[t]{2}{*}{ Form } & Normal release & $\mathrm{n}(\%)$ & $5(50 \%)$ & $70(70 \%)$ & \multirow{2}{*}{$\begin{aligned} & X^{2} \\
= & 0.881\end{aligned}$} & \multirow[t]{2}{*}{0.348} \\
\hline & SR & $\mathrm{n}(\%)$ & $5(50 \%)$ & $30(30 \%)$ & & \\
\hline \multirow{3}{*}{$\begin{array}{c}\text { Dose } \\
\text { (tablet }=400 \mathrm{mg})\end{array}$} & \multicolumn{2}{|c|}{ Minimum } & 1 & 2 & \multirow{3}{*}{$\begin{aligned} & \mathrm{Z}_{\mathrm{mw}} \\
= & 2.528\end{aligned}$} & \multirow[t]{3}{*}{0.011} \\
\hline & Maxim & & 20 & 20 & & \\
\hline & Medi & & 8 & 5 & & \\
\hline \multirow[t]{3}{*}{ Delay (h) } & Minim & & 1 & 1 & \multirow{3}{*}{$\begin{aligned} & Z_{\mathrm{mw}} \\
= & 0.710\end{aligned}$} & \multirow[t]{3}{*}{0.478} \\
\hline & Maxim & & 24 & 26 & & \\
\hline & Medi & & 4.5 & 6 & & \\
\hline
\end{tabular}

$P^{*}<0.05$ = significant; $n:$ number; ICU: intensive care unit 
Table 4: Association between ICU admission and clinical findings in acute theophylline intoxicated patient (n=110)

\begin{tabular}{|c|c|c|c|c|c|}
\hline \multirow{2}{*}{\multicolumn{2}{|c|}{ Clinical findings }} & \multirow{2}{*}{\multicolumn{2}{|c|}{ ICU admission }} & \multirow{2}{*}{\multicolumn{2}{|c|}{ Chi Square test }} \\
\hline & & & & & \\
\hline Naucen & Yes & $\begin{array}{c}\text { Yes (n=10) } \\
\mathbf{n}(\mathbf{\%})\end{array}$ & $\begin{array}{c}\text { No }(\mathbf{n}=100) \\
\mathbf{n}(\mathbf{\%})\end{array}$ & \multirow{2}{*}{$\begin{array}{c}\mathbf{X}^{2} \\
1.038\end{array}$} & $\begin{array}{c}\text { P value } \\
0.308\end{array}$ \\
\hline & No & $0(0 \%)$ & $18(18 \%)$ & & \\
\hline \multirow[t]{2}{*}{ Vomiting } & Yes & $9(90 \%)$ & $90(90 \%)$ & \multirow[t]{2}{*}{5.54} & \multirow[t]{2}{*}{0.092} \\
\hline & No & $1(10 \%)$ & $10(10 \%)$ & & \\
\hline \multirow[t]{2}{*}{ Hematemesis } & Yes & $1(10 \%)$ & $7(7 \%)$ & \multirow[t]{2}{*}{0.000} & \multirow[t]{2}{*}{1.000} \\
\hline & No & $9(90 \%)$ & 93 (93\%) & & \\
\hline \multirow[t]{2}{*}{ Diarrhea } & Yes & $1(10 \%)$ & $3(3 \%)$ & \multirow[t]{2}{*}{0.058} & \multirow[t]{2}{*}{0.809} \\
\hline & No & $9(90 \%)$ & 97 (97\%) & & \\
\hline \multirow[t]{2}{*}{ Tremors } & Yes & $9(90 \%)$ & $26(26 \%)$ & \multirow[t]{2}{*}{14.34} & \multirow{2}{*}{$\begin{array}{l}<0.001 \\
*\end{array}$} \\
\hline & No & $1(10 \%)$ & $74(74 \%)$ & & \\
\hline \multirow[t]{2}{*}{ Agitation } & Yes & $7(70 \%)$ & $1(1 \%)$ & \multirow[t]{2}{*}{54.36} & \multirow{2}{*}{$\begin{array}{l}<0.001 \\
*\end{array}$} \\
\hline & No & $3(30 \%)$ & 99 (99\%) & & \\
\hline \multirow[t]{2}{*}{ Hallucinations } & Yes & $2(20 \%)$ & $0(0 \%)$ & \multirow[t]{2}{*}{37.155} & \multirow[t]{2}{*}{$0.008 *$} \\
\hline & No & $8(80 \%)$ & $100(100 \%)$ & & \\
\hline \multirow[t]{2}{*}{ Seizures } & Yes & $1(10 \%)$ & $0(0 \%)$ & \multirow[t]{2}{*}{2.044} & \multirow[t]{2}{*}{0.153} \\
\hline & No & $9(90 \%)$ & $100(100 \%)$ & & \\
\hline
\end{tabular}

$P^{*}<0.05$ = significant; $n:$ number; ICU: intensive care unit

Table 5: Association between ICU admission and vital data and laboratory findings in acute theophylline intoxicated patient $(\mathbf{n}=110)$

\begin{tabular}{|c|c|c|c|c|c|c|}
\hline \multirow{2}{*}{\multicolumn{3}{|c|}{ Clinical and laboratory findings }} & \multirow{2}{*}{\multicolumn{2}{|c|}{ ICU admission }} & \multirow{2}{*}{\multicolumn{2}{|c|}{ Chi Square test }} \\
\hline & & & & & & \\
\hline Blond nressure & Hynotension & $n(\%)$ & $\begin{array}{c}\begin{array}{c}\text { Yes } \\
(\mathbf{n}=\mathbf{1 0})\end{array} \\
7(70 \%)\end{array}$ & $\begin{array}{r}\begin{array}{r}\text { No } \\
(\mathbf{n}=\mathbf{1 0 0})\end{array} \\
6(6 \%) \\
\end{array}$ & \multirow{2}{*}{29.85} & \multirow{2}{*}{$<0.001^{*}$} \\
\hline & Normal & n (\%) & $3(30 \%)$ & $\begin{array}{c}94 \\
(94 \%)\end{array}$ & & \\
\hline \multirow[t]{2}{*}{ Pulse } & Tachycardia & n (\%) & $8(80 \%)$ & $\begin{array}{c}91 \\
(91 \%)\end{array}$ & \multirow[t]{2}{*}{0.306} & \multirow[t]{2}{*}{0.580} \\
\hline & Normal & n (\%) & $2(20 \%)$ & $9(9 \%)$ & & \\
\hline \multirow[t]{2}{*}{ Temperature } & High & n (\%) & $0(0 \%)$ & $3(3 \%)$ & \multirow[t]{2}{*}{0.000} & \multirow[t]{2}{*}{1.000} \\
\hline & Normal & n (\%) & $10(100 \%)$ & $\begin{array}{c}97 \\
(97 \%)\end{array}$ & & \\
\hline \multirow[t]{3}{*}{$\begin{array}{l}\text { Serum Potassium } \\
\text { level }(\mathrm{mEq} / \mathrm{L})\end{array}$} & Hypokalemia & n (\%) & $9(90 \%)$ & $\begin{array}{c}73 \\
(73 \%)\end{array}$ & \multirow[t]{3}{*}{8.46} & \multirow[t]{3}{*}{$0.012 *$} \\
\hline & Hyperkalemia & n (\%) & $1(10 \%)$ & $0(0 \%)$ & & \\
\hline & Normal & n (\%) & $0(0 \%)$ & $\begin{array}{c}27 \\
(27 \%)\end{array}$ & & \\
\hline \multirow[t]{2}{*}{$\begin{array}{l}\text { Serum glucose level } \\
(\mathrm{mg} / \mathrm{dl})\end{array}$} & Hyperglycemia & n (\%) & $2(20 \%)$ & $\begin{array}{c}27 \\
(27 \%)\end{array}$ & \multirow[t]{2}{*}{0.011} & \multirow[t]{2}{*}{0.918} \\
\hline & Normal & n (\%) & $8(80 \%)$ & $\begin{array}{c}73 \\
(73 \%)\end{array}$ & & \\
\hline \multirow{3}{*}{$\begin{array}{l}\text { Serum theophylline } \\
\text { level (mg/L) }\end{array}$} & \multicolumn{2}{|c|}{ Minimum } & 19 & 8.8 & \multirow[t]{3}{*}{-2.584} & \multirow[t]{3}{*}{ 0.010* } \\
\hline & \multicolumn{2}{|c|}{ Maximum } & 126 & 80 & & \\
\hline & \multicolumn{2}{|c|}{ Median } & 63 & 33 & & \\
\hline
\end{tabular}

$P^{*}<0.05$ = significant; $n:$ number; ICU: intensive care unit

Table (6): A logistic regression for prediction of ICU admission in acute theophylline intoxicated patient (n=110)

\begin{tabular}{|l|c|c|c|c|c|c|c|}
\hline \multicolumn{1}{|c|}{ Variables } & $\begin{array}{c}\text { B } \\
\text { coefficient }\end{array}$ & $\begin{array}{c}\text { Odds } \\
\text { ratio }\end{array}$ & $\boldsymbol{P}$ value & $\begin{array}{c}\text { Overal } \\
\text { I accuracy }\end{array}$ & $\mathbf{R} 2$ & $\mathbf{X}^{\mathbf{2}}$ & $\boldsymbol{P}$ value \\
\cline { 1 - 4 } Hallucination & 36.72 & 8.85 & $<0.001^{*}$ & $98.2 \%$ & $88.4 \%$ & 56.78 & $<0.001^{*}$ \\
\cline { 1 - 4 } Hypotension & 18.70 & 131.85 & $0.017^{*}$ & & & \\
\hline
\end{tabular}

$P^{*}<0.05=$ significant 
Table (7): The best cut-off value, sensitivity, specificity, and AUC of serum theophylline level for predicting ICU admission in acute theophylline intoxicated patient $(\mathbf{n}=110)$.

\begin{tabular}{|c|c|c|c|c|c|}
\hline Variable & $\begin{array}{c}\text { Cut-off } \\
\text { value }(\mathbf{m g} / \mathbf{L})\end{array}$ & Sensitivity \% & Specificity \% & $\begin{array}{c}\text { ROC- } \\
\text { AUC }\end{array}$ & $\begin{array}{c}\boldsymbol{P} \\
\text { value }\end{array}$ \\
\hline $\begin{array}{c}\text { Serum Theophylline } \\
\text { level }\end{array}$ & $\geq 37.5$ & 80 & 58 & 0.75 & $0.010^{*}$ \\
\hline
\end{tabular}

$P^{*}<0.05=$ significant

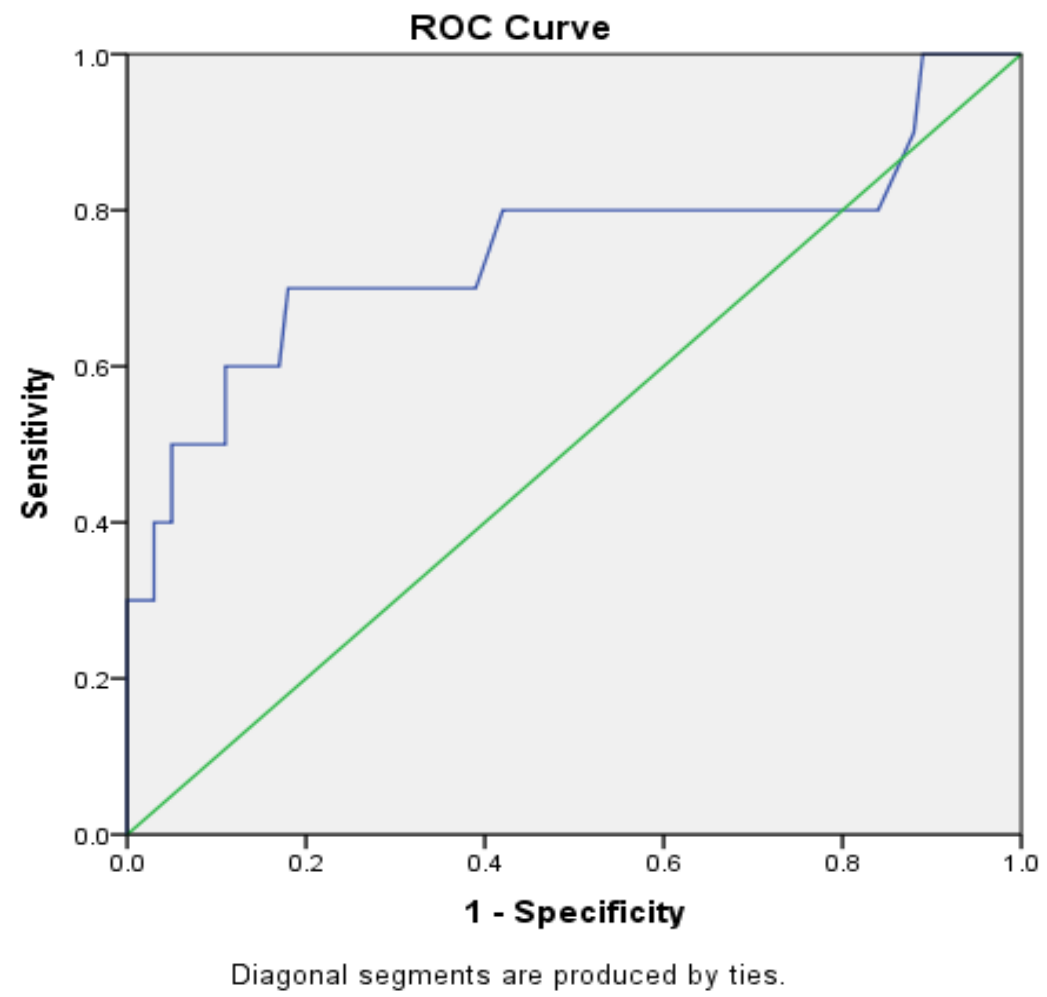

Figure (1): ROC curve of serum theophylline level for predicting ICU admission in acute theophylline intoxicated patients $(n=110)$.

\section{Discussion}

Theophylline is a commonly used drug in the treatment of acute or chronic lung disease. Despite the considerable potential benefit of theophylline, its narrow therapeutic range and erratic absorption and elimination contribute to the potential for toxicity, which can have high morbidity and mortality (Yaman et al., 2016). Theophylline intoxication may be acute, acute on therapeutic or chronic (Henry and Minton, 2011). Both intentional and accidental toxicity are common due to its wide availability (Lim et al., 2005).

The main findings of this research confirmed that the mean age, gender, residence, route \& mode of poisoning and clinical data were more or less in agreement with many previous observations in majority of centers in Egypt and across the world (Minton and Henry 1996; Shannon, 1999; Shannon, 2000; Borkan, 2002; Kumar and Moses, 2004; Shannon, 2007; Shannon, 2008; Tesfaye et al., 2008; National
Toxicology Program, 2010; Mohammed, 2011; Yip et al., 2011; El-Hawary, 2015).

This observation cross sectional study of acute theophylline intoxication was designed to clarify the best predictors for ICU admission in acute theophylline poisoning. In order to achieve this target, sociodemographic, toxicological, clinical data and laboratory findings were analyzed against ICU admission in acute theophylline poisoned patients.

This analysis revealed that, no statistical significant association was detected between need for ICU admission and age, pre-existing disease, form of theophylline preparation, time of delay, mode, route, and type of toxicity. Moreover, nausea, vomiting, hematemesis diarrhea and seizures registered no statistical significant association with need for ICU admission. Furthermore, pulse, temperature and serum glucose level showed no statistical significant association with need for ICU admission. Henceforth, it anticipated 
to exclude these variants from logistic regression for prediction of ICU admission in patients with acute theophylline toxicity.

Statistical significant association was found between ICU admission and gender within the studied patients. This could be explained through the reported predominance of females over males in the current study which is supported by Yip et al. (2011). This finding was comparable with previous studies which reported that, numbers of intoxicated females admitted to ICU were greater than males (Viertel et al., 2001; Tufekci et al., 2004; Guloglu and Kara, 2005; Cengiz, et al., 2006). These data were controversial to data gathered by other authors who registered about $47.4 \%$ of intoxicated, ICU admitted patients were male (Mucci et al., 2006; Cook et al., 2008; Sulaj et al., 2015).

Statistical significant association was found between ICU admission and doses. This may be attributed to the large inter individual variation in theophylline kinetics. The absorption of theophylline is largely affected by the presence of food in stomach and/or recumbence. Additionally, the metabolism and the clearance of theophylline are influenced by a large number of factors (Undem, 2006).

Patients in the current study showed variable CNS manifestations ranged from tremors, agitations, and hallucinations. Such finding is comparable to Shannon (2000) who reported an incidence of hallucinations and agitation in his study. On the other hand, all studied cases were fully conscious and alert on admission.

Theophylline stimulates central nervous system (CNS) at various levels. Stimulation of the cerebral cortex leads to agitation, tremors, restlessness, irritability and headache. Moreover, stimulation of the spinal cord results in hyperreflexia (Caravati, 2004). Furthermore, CNS effects of theophylline are mediated through increased cyclic-AMP concentration and blockage of adenosine receptors which results in CNS stimulation at various levels according to Shannon (2008).

Statistical significant association was found between need for ICU admission and different CNS manifestations including agitations, hallucinations and tremors within the studied patients. This finding might be attributed to correlation between methylxanthine concentrations in the cerebrospinal fluid and those in plasma (Ghannoum et al., 2015). Henceforth, central nervous system stimulation is a hallmark of methylxanthine toxicity and could be a predictor for ICU admission.

This finding is supported by Shannon (2007) who reported that neurological toxic manifestations due to theophylline toxicity are considered a predictor of poor outcome. In addition, patients experiencing neurological toxic manifestations of theophylline toxicity may suffer from serious complications or even permanent neurological infirmity. Furthermore, Lim et al. (2005) and Hoffman (2006) reported that neurological manifestations such as anxiety, agitation, hallucinations and/or seizures could worsen the clinical outcome of patients with theophylline toxicity.

In the present study, there was statistical significant association between ICU admission and hypotension in acute theophylline poisoned patients. Borkan (2002) clarified that, hypotension may occur with acute theophylline toxicity as a result of volume depletion and/or vasodilatation. Furthermore, Rahat et al. (2005) concluded that severe hypotension not responding to treatment can be considered as a risk factor for severe theophylline toxicity and poor outcome.

In (2005) Rahat and his colleges found an association between serum potassium level and severity of theophylline toxicity. This data could explain the statistical significant association registered between and serum potassium level. Moreover, high incidence of hypokalemia was reported by both Shannon (1999) and Amin et al. (2003) in acute theophylline poisoned patients. It is usually attributed to intracellular movement of potassium induced by excess catecholamines secretion (Hoffman, 2006).

Serum theophylline level showed statistical significant association with ICU admission in the participating patients. In the same direction, Sessler (1990), Shannon (1993), Shannon (1999), Visitsunthorn et al. (2001) \&Shannon and Perry (2005) supposed that, high-risk patients could be identified using peak serum theophylline concentration in acute theophylline intoxication. In contrast Aitken and Martin (1987) \& Bertino and Waiker (1987) found that the peak serum theophylline concentration was not associated with major toxicity. However, patients included in both studies were acute on top of chronic toxicity and none of them had acute toxicity from single overdose.

Logistic regression of clinically relevant variable showed that, patients who presented with hallucination, agitation, or hypotension had an increased likelihood of requiring admission to ICU. ROC curve analysis of serum theophylline accuracy in predicting need for ICU admission revealed that, serum level $\geq 37.5$ $\mathrm{mg} / \mathrm{L}$ is a fair predictor.

\section{Conclusion}

From this study, it could be concluded that, in acute theophylline intoxicated patients, hallucination, agitation and hypotension could be considered as good predictors for ICU admission. Additionally, serum theophylline level $\geq 37.5 \mathrm{mg} / \mathrm{L}$ is a fair predictor.

\section{Recommendations}

It is recommended to consider ICU admission for acute theophylline intoxicated patients suffering from hallucination, agitation and hypotension to help young clinician to identify critical cases of acute theophylline toxicity in initial assessment in ED. Theophylline intoxicated patients who are presented by serum theophylline level of $\geq 37.5 \mathrm{mg} / \mathrm{L}$ should be admitted in ICU as high risk patients.

Further researches are required to investigate prognosis and course of theophylline acute intoxicated 
patients admitted to the intensive care unit. Striking lack of correlation of peak serum theophylline concentrations with clinical course for those with chronic theophylline toxicity makes further studies rational to find predictors that reflect clinical condition and ICU requirement of patients whether they are acutely or chronically exposed to theophylline toxicity.

\section{Study limitation}

The principal limitation of the current study is its small sample size precipitated by small number of theophylline intoxicated patients presented to Poison Control Unit, Emergency Hospital, Tanta University. Moreover, absence of chronic exposed theophylline intoxicated patients who require further investigation.

\section{References}

Aitken ML and Martin TR (I987): Life-threatening theophylline toxicity is not predictable by serum levels. J. Chest. 91(1): 10-14.

Amin R, Alyasin S and Rahmani G (2003): Theophylline induced alteration in serum electrolytes and uric acid of asthmatic children. Iranian Journal of Asthma Allergy and Immunology. 2: 31-37.

Bertino JS and Waiker JW (1987): Reassessment of theophylline toxicity: serum concentrations, clinical course, and treatment. Arch. Intern. Med. 147(4):757-760.

Borkan S (2002): Extracorporeal therapies for acute intoxications. Critical Care Clinics. J. 18:393420.

Boushey H (2011): Drugs used in asthma, In: Basic and Clinical Pharmacology, Katzung B, Masters S and Trevor (eds), $11^{\text {th }}$ ed., McGraw Hill, London, pp. 339-356.

Caravati E (2004): Smooth Muscle Relaxants, In: Medical toxicology, Dart R (eds), $3^{\text {rd }}$ ed., Lippincott Williams \& Wilkins, Philadelphia, pp. 1009-1013.

Cengiz M, Baysal Z, Ganidagli S et al., (2006): Characteristics of poisoning cases in adult intensive care unit in Sanliurfa, Turkey. Saudi Med. J. 27 (4): 497-502.

Cook R, Allcock R and Johnston M (2008): Selfpoisoning: current trends and practice in a U.K. teaching hospital. Clin. Med. 8(1):37-40.

Davies J, Eddleston M and Buckley N (2008): Predicting outcome in acute organophosphorus poisoning with a poison severity score or the Glasgow coma scale. Q. J. Med. 101: 371-379.

El-Hawary A, El-Gazzar F and El-Ebiary A (2015): Predictors of acute theophylline toxicity outcomes. Mansoura J. Forens. Med. Clin. Toxicol. 23(1): 29-49.

Flomenbaum N, Goldfrank L, Hoffman R et al., (2006): Initial Evaluation of the Patient: Vital Signs and Toxic Syndromes, In: Goldfrank's Toxicological Emergencies, Flomenbaum N, Goldfrank L, Hoffman R et al., (eds), $8^{\text {th }}$ ed., McGraw Hill, London, pp. 37-42.
Ghannoum M, Wiegand TJ, Liu KD et al., (2015): Extracorporeal treatment for theophylline poisoning: systematic review and recommendations from the EXTRIP workgroup. Clinical Toxicology. 53(4): 215-229.

Guloglu C and Kara IH (2005): Acute poisoning cases admitted to a university hospital emergency department in Diyarbakir, Turkey. Hum. Exp. Toxicol. 24: 49-54.

Hartman M and Cheifetz I (2011): Pediatric Emergencies and Resuscitation, In: Nelson text book of pediatrics, Kliegman R, Stanton B, Geme J et al., (eds), $19^{\text {th }}$ ed., Elsevier Saunders Inc, Philadelphia, pp. 279-296.

Henry J and Minton N (2011): Treatment of theophylline overdose. Amer. J. of Emerg. Med. 14:606-612.

Hoffman R (2006): Methylxanthines and selective B2 adrenergic agonist, In: Goldfrank's toxicological emergencies, Boyle $\mathrm{P}$, Edmonson $\mathrm{K}$ and Wonsiewicz M (eds), $8^{\text {th }}$ ed., McGraw-Hill, London, pp. 989-1000.

Kapoor S, Thakkar J and Aggarwal V (2015): Theophylline toxicity leading to suicidal ideation in a patient with no prior psychiatric illness. SAGE open medical case reports, 3, $2050313 X 15583208$.

Knapp H (2017): Introductory Statistics Using SPSS. SAGE Publications, Inc.

Koeijers JJ, Verhoeven CL, Boersma HH et al., (2008): Treatment of theophylline intoxication using continuous venovenous haemofiltration. Neth. J. Crit. Care. 12: 32-34.

Kumar TS and Moses PD (2004): Acute respiratory infection with CNS excitation symptomsconsider theophylline over- dosage. Indian Pediatr. J. 41:1066-1067.

Liisanantti J, Ohtonen P, Kiviniemi O et al., (2011): Risk factors for prolonged intensive care unit stay and hospital mortality in acute drug-poisoned patients: An evaluation of the physiologic and laboratory parameters on admission. Journal of Critical Care. 26:160-165.

Lim S, Tan S, Tai D et al., (2005): Successful treatment of theophylline toxicity with continuous venovenous haemofiltration. Critical Care and Shock Journal. 8:96-97.

Minton NA and Henry JA (1996): Acute and chronic human toxicity of theophylline. Hum. Exp. Toxicol. 15:471-481.

Mohammed SS (2011): Retrospective study of acute theophylline intoxicated cases admitted to poison control center-Ain Shams University. Master thesis in Forensic Medicine and Clinical Toxicology, Faculty of Medicine, Ain Shams University.

Mucci N, Alessi M, Binetti R et al., (2006). Profile of acute poisoning in Italy. Analysis of the data reported by Poison Centres. Annali dell'Istituto 
superiore di sanita. 42(3): 268-276.

National Toxicology Program (2010): Home $>>$ Testing Information $>>$ Testing status of agents at: http://www.niehs.nih.gov/about/assets/do cs/update_ntp_feb2010_508.pdf.

Nield L and Kamat D (2011): Fever, In: Nelson text book of pediatrics, Kliegman R, Stanton B, Geme J et al., (eds), $19^{\text {th }}$ ed., Elsevier Saunders Inc, Philadelphia, pp. 896.

Paul S, Saba M and Berger K (2010): Theophylline in Asthma. Journal of Asthma \& Allergy Educator. 1 (5):180-182.

Rahat k, Baljit S and Narinder S (2005): Review of management of common poisoning in India. Ind. Medica. J. 5: 4-6.

Sessler CN (1990): Theophylline toxicity: clinical features of 116 consecutive cases. Am. J. Med. 88:567-576.

Shannon M (1993): Predictors of major toxicity after theophylline overdose. Ann. Intern. Med. 119:1161-1167.

Shannon M (1999): Life threatening events after theophylline overdose. Arch. Intern. Med. 159:989-994.

Shannon M (2000): Theophylline: its rise, demise and resurrection. Clin. Ped. Emerg. Med. J.1:213.

Shannon M (2007): Theophylline and Caffeine, In: Haddad and Winchester Clinical management of poisoning and drug overdose, Shannon $\mathrm{M}$, Borron S and Burns M (eds), $4^{\text {th }}$ ed., Elsevier Inc Company, Philadelphia, pp. 1035-1094.

Shannon M (2008): Methylxanthines Poisoning, In: Irwin and Rippe's intensive care medicine, Linden $\mathrm{HC}$ and Bird BS (eds), $6^{\text {th }}$ ed., Lippincott Williams \& Wilkins, Philadelphia, pp. 1647.

Shannon M and Perry E (2005): Theophylline and other Methyl Xanthine, In: Critical Care Toxicology: Diagnosis and Management of the Critically Poisoned Patients, Brent J (eds), $1^{\text {st }}$ ed., Elsevier Health Sciences, Ch 40. pp. 458-464.
Sheehan M and Haythorn P (1976): Rapid gas chromatographic determination of underivatized theophylline in whole blood. J. Chromatogr. 117:392-398.

Sulaj Z, Prifti E, Demiraj A et al., (2015): Early clinical outcome of acute poisoning cases treated in intensive care unit. Med. Arh. 69(6): 400-404.

Tesfaye H, Prusa R and Doupovcová J (2008): Hypokalemia in a suicide attempt of an adolescent girl. Casopis Lekaru Ceskych J.147:333-336.

Tufekci I, Curgunlu A and Sirin F (2004): Characteristics of acute adult poisoning cases admitted to a university hospital in Istanbul. Hum. Exp. Toxicol. 23: 347-351.

Undem B (2006): Pharmacotherapy of asthma, In: Goodman and Gilman's the pharmacology basis of therapeutics, Brunton L, Lazo L and Parker S (eds), $11^{\text {th }}$ ed., McGraw Hill, London, pp. 717736.

Viertel A, Weidmann E and Brodt H (2001): Cases of acute poisoning admitted to a medical intensive care unit. Dtsch Med Wochenschr. 126: 11591163.

Visitsunthorn N, Udomittipong $\mathrm{K}$ and Punnakan L (2001): Theophylline Toxicity in Thai Children. Asian Pacific Journal of Allergy and Immunology. 19(3):177-182.

Wu JP, Wu Q, Sun X et al., (2013): Corticosteroid resistance in chronic obstructive pulmonary disease: new uses of theophylline. Chin. Med. J. 126: 965- 970.

Yaman A, Kendirli T, Ödek Ç et al., (2016): Severe theophylline poisoning treated with continuous venovenous hemodialysis in a child. The Turkish Journal of Pediatrics. 58(3): 297-300.

Yip WL, Tse ML, Lau FL et al., (2011): An Epidemiological Study of Pediatric Poisoning in Hong Kong. Hong Kong J. of Pedi. 16:25-31. 


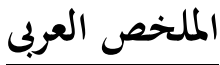

\section{مؤشرات التنبؤ بدخول وحدة العناية المركزة في مرضى التسمم الحاد بالثيوفيلين}

\section{هبd كامل خليفة و هبه ابراهيم لاشين}

لا يزال الثيوفيلين من المستحضرات الصيدلانية الأكثر انتشاراً لعلاج الربو الحساد والمزمن في العديد من البلدان النامية لأنه فعال ورخيص ومتاح على نطاق واسع. وقد تم التحقق في عدد قليل من الدراسات من التنبؤ بالحاجة إلى دخول وحدة العناية المركزة على أساس المعاملات السريرية المسجلة عند الدخول.

وبالتالي تمدف هذه الدراسة الى تحديد مؤشرات التنبؤ بدخول وحدة العناية المركزة فن مرضى التسمم الحاد بالثيوفيللين. أجريت هذه الدراسة على مائة وعشرة من مرضى التسمم الحاد بالثيوفيلين و الذين تم إدخالهم إلى وحلدة مكافحة التسمم ، مستشفى الطوارئ ، جامعة طنطا خلال فترة عامين.

تم إجراء فحص اجتماعي وديموغرافي و فحص سُمي و تقييم إكلينيكي و فحوصات مختبرية روتينية ومستوى الثيوفيلين بالدم لكل مريض. تم تحليل جميع نتائج مرضى التسمم الحاد بالثيوفيلين احصائيا مع الدخول لوحدة العناية المركزة. وقد وجدت ارتباطات إحصائية هامة

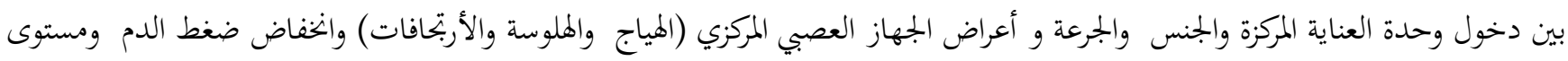

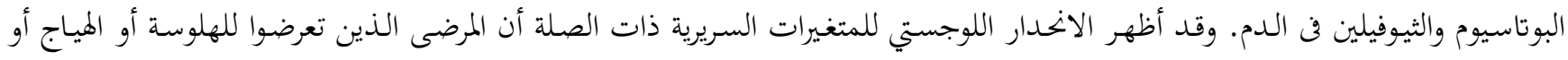

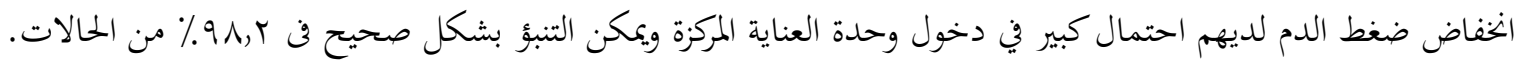
كما أظهر التحليل الإحصائى أن مستوى الثيوفيلين بالدم أعلى من أو يساوى العناية المركزة. ويمكن الاستنتاج أن في مرضى التسمم الحاد بالثيوفيلين يمكن اعتبار الهلوسة و الهياج وانخفاض ضغط الدئل الدم مؤشرات جيدة لدخول

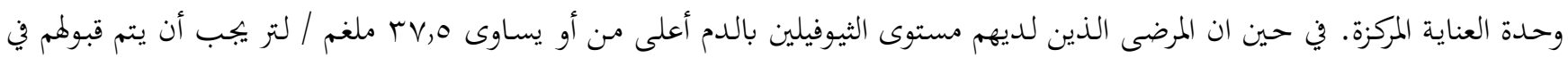
وحدة العناية المركزة كمرضى أصحاب مخاطر عالية. 